J. Asiat. Soc. Bangladesh, Sci. 38(1): 75-82, June 2012

\title{
HOST PREFERENCE OF PUMPKIN BEETLE TO CUCURBITS UNDER FIELD CONDITIONS
}

\author{
M. M. H. KHAN \\ Department of Entomology, Patuakhali Science and Technology University, \\ Dumki, Patuakhali, Bangladesh
}

\begin{abstract}
To find out preferred cucurbit host(s) of the pumpkin beetle and to determine the susceptibility of ten different cucurbits to the pest, a trial was conducted under field conditions. The results revealed that the most preferred host of the red pumpkin beetle (RPB) was muskmelon, which was followed by khira, cucumber and sweet gourd, and these may be graded as susceptible hosts. Bitter gourd, sponge gourd, ribbed gourd and snake gourd were least or non preferred hosts of RPB and these may be graded as resistant hosts. Other two crops, the bottle gourd and ash gourd were moderately preferred hosts of the insect and these may be graded as moderately susceptible hosts. The order of the most preferred host of the blue pumpkin beetle may be shown as bitter gourd $>$ ribbed gourd $>$ sponge gourd. Of these cucurbits, population of blue pumpkin beetle was much higher than that of red pumpkin beetle. The hosts most preferred to RPB are less preferred or not preferred to the blue pumpkin beetle. The field trials revealed that the order of preference of RPB for ten tested cucurbit hosts was muskmelon $>$ sweet gourd $>$ cucumber $>$ khira $>$ ash gourd $>$ bottle gourd $>$ sponge gourd $\geq$ ribbed gourd $\geq$ snake gourd $>$ bitter gourd.
\end{abstract}

Key words: Host preference, pumpkin beetle, cucurbits

\section{Introduction}

The family Cucurbitaceae comprises more than 700 species of plants in about 90 genera (York 1992). Cucurbits are among the most widely grown and important crops in the tropical and subtropical countries of the world. Pumpkin beetle is the major pest and causes considerable damage to almost all cucurbitaceous crops (Butani and Jotwani 1984, Yawalkar 1985). Among different species of pumpkin beetles, incidence of adult stage of the red pumpkin beetle (RPB), Aulacophora foveicollis (Lucas) on different cucurbits have been reported by various workers (Nath 1964, Nath and Thakur 1965, Bogawat and Pandey 1967). The pest, however, occurs throughout the year and causes severe damage to the crops, especially at the seedling stage (Alam 1969, Butani and Jotwani 1984). The adult beetles feed voraciously on the cucurbit leaf making irregular holes. They also attack cotyledons and flowers (Butani and Jotwani 1984). The beetles may kill seedlings and sometimes the crops have to be resown 3-4 times (Azim 1966). The grubs feed on roots and underground portions of the host plants as well as fruits touching the soil and thus making such fruits unsuitable for human consumption (Butani and Jotwani 1984). It may cause up to $70 \%$ damage to the leaves and $60 \%$ to the flowers of cucumber plants (Alam 1969). 
According to Nath and Thakur (1965), among the gourds, sponge gourd was found to be least preferred by RPB, while the bottle gourd was most preferred and the ridge gourd was intermediate in reaction. Khan and Hajela (1987) found that RPB preferred sweet gourd followed by cucumber, squash melon, sponge gourd and bottle gourd. Dilon and Sharma (1989) observed significant varietal differences for resistance to RPB in summer squash both in the field and in cage experiments.

Report on host preference of pumpkin beetle to different cucurbit hosts is scanty in Bangladesh. If the most preferred cucurbit host plant could be identified, it may be used as a trap or barrier crop to decrease infestation on target cucurbits. In addition, this preferred cucurbit crop may be grown as one of the component crops of mixed cropping to support higher pumpkin beetle load compared to other cucurbits. Therefore, it needs to identify the less and the most preferred cucurbits to pumpkin beetle. The present study was undertaken to find out host preference of the pumpkin beetles and to determine susceptibility of different cucurbit hosts to the pest.

\section{Materials and Methods}

The experiment was conducted in the experimental field of the Department of Entomology, Bangabandhu Shiekh Mujibur Rahman Agricultural University (BSMRAU) Salna, Gazipur during March-June 2007. Ten different cucurbit crops viz., sweet gourd (Cucurbita moschata L.), bottle gourd (Lagenaria siceraria L.), ash gourd (Benincasa hispida L.), bitter gourd (Momordica charantia L.), sponge gourd (Luffa cylindrica L.), ribbed gourd (Luffa acutangula L.), snake gourd (Trichosanthes anguina L.), cucumber (Cucumis sativus L.), khira (Cucumis sativus L.), and muskmelon (Cucurbita melo L.) were grown in the experimental fields following randomized complete block design with 4 replications. The size of the unit plot was $4 \mathrm{~m} \times 4 \mathrm{~m}$ with an inter plot distance of $1 \mathrm{~m}$ and row to row distance $1.5 \mathrm{~m}$. Two pits of $30 \mathrm{~cm} \times 30 \mathrm{~cm} \times 20 \mathrm{~cm}$ were dug at one side of each plot at a distance of $2 \mathrm{~m}$ to facilitate well spreading of cucurbit vines and also for easy inspection and data recording. Cow dung and fertilizer were applied as recommended (Rashid 1993) for cucurbits at the rate of 10,000, 69, 60 and $60 \mathrm{~kg}$ of cow dung, N, P and K per hectare, respectively. The half of cow dung, TSP and MP, and one third of urea were applied as basal dose during land preparation. The remaining cow dung, TSP and MP were applied in the pit 15 days before transplanting the seedlings. The rest of urea was top dressed after each flush of flowering and fruiting in three equal splits.

The seeds of different cucurbits were procured from Siddique Bazar, Dhaka. Prior to sowing, the seeds of bitter gourd and bottle gourd were soaked in water for about 12 hours to hasten uniform germination. The seeds were sown on $3^{\text {rd }}$ March 2007 in polythene bag $(15 \mathrm{~cm} \times 10 \mathrm{~cm})$ containing $50 \%$ well-decomposed cow dung and $50 \%$ sandy loam soil. Two seedlings of 15 days old were planted in each of the two pits. Irrigation and other recommended agronomic practices were followed as suggested by Rashid (1993). The crop was kept under constant observation from 2 leaf stage to 28 days 
for recording data on incidence of pumpkin beetles. The susceptibility of different cucurbits to the pumpkin beetle was observed on the basis of beetle populations and damage caused by them.

Adult pumpkin beetles per plant: The number of the adult pumpkin beetles per plant was recorded through visual observations on upper and lower surfaces of leaves during 7-28 days after transplanting (DAT). The observation was made in the morning at 7:00, 8:00 and 9:00 AM and in the afternoon at 4:00, 5:00 and 6:00 PM. As the beetles are agile, observation was made very carefully without knocking the leaves and touching the plants. Average number of adult beetles per plant at different DAT was computed.

Per cent infestation of leaves: Data on leaf infestation per plant were converted to mean number recorded at 7, 14, 21 and 28 DAT. Per cent leaf infestation per plant was determined using the following simple formula:

$$
\text { Infestation of leaves }(\%)=\frac{\text { Number of infested leaves }}{\text { Total number of leaves }} \times 100
$$

Data collected from the experiment were statistically analyzed using MSTAT-C software. Whenever necessary data were transformed following square root or Arc Sin transformation before analysis. Means were separated by the Duncan's Multiple Range Test (Steel and Torrie 1960).

\section{Results and Discussion}

Incidence of pumpkin beetle at different days after transplanting: At 7 days after transplanting, the highest number of the red pumpkin beetle (RPB) was recorded on muskmelon (3.00), which was followed by sweet gourd (2.75), cucumber (2.50) and khira (2.00). Occurrence of the beetle on those four crops was statistically similar but significantly higher as compared to other crops. At this stage, bottle gourd and ash gourd showed statistically similar number of the beetle. It was significantly higher as compared to sponge gourd and ribbed gourd which had less than one beetle per plant. Bitter gourd and snake gourd were free from RPB (Table 1).

At 14 DAT, bitter gourd, sponge gourd, ribbed gourd and snake gourd were found to be free from infestation of RPB. Its occurrence was maximal on muskmelon, which was statistically similar to khira, cucumber and sweet gourd. Number of RPB on bottle gourd and ash gourd was also statistically similar but significantly lower as compared to above four crops and higher as compared to other crops (Table 1).

At 21 DAT, occurrence of RPB on muskmelon, cucumber and sweet gourd was also statistically similar but significantly higher as compared to other crops. The insect was absent from sponge gourd and ribbed gourd. Its occurrence on bitter gourd and snake gourd was less than one per plant. Other three crops showed 1.75-2.25 insects per plant per day, which were statistically similar. 
At 28 DAT, number of RPB on muskmelon was significantly higher as compared to other crops except the sweet gourd. Occurrence of the insect on sweet gourd, bitter gourd, ash gourd, cucumber and khira ranged from 1.50 to 3.00 per plant, which was statistically similar. Other three crops had less than one insect per plant (Table 1).

Results of the experiment indicate that the most preferred host of RPB is muskmelon, which was followed by khira, cucumber and sweet gourd. These may be graded as susceptible hosts. On the other hand, bitter gourd, sponge gourd, ribbed gourd and snake gourd are least or non-preferred hosts of RPB. They may be graded as resistant hosts. Other two crops bottle gourd and ash gourd were moderately preferred hosts of the insect and may be graded as moderately susceptible hosts (Table 1).

Host preference of a particular insect pest depends upon the quality of host plants, which influences the growth and development of the pest. Thus the order of preference of different cucurbits as a host of RPB might be attributed to its nutrient contents that enhance the growth and development of the pest. Begum (2002) reported that among the five cucurbit plants (viz., sweet gourd, ash gourd, sponge gourd, snake gourd and cucumber), sweet gourd was identified as the most susceptible and highly preferred host to red pumpkin beetle and cucumber was recognized as less susceptible and less preferred host to this pest. Red pumpkin beetle is a polyphagous pest and prefers cucurbit, vegetables and melons (Butani and Jotwani 1984). This beetle is particularly a severe pest of pumpkins, muskmelons and bottle gourds (Rahman and Annadurai 1985) and attacks cucumber, melon and gourds (Abdullah 1969). In almost all cases, findings of the present studies are in agreement with the findings of other investigators.

Table 1. Incidence of pumpkin beetle per plant on different cucurbit host plants at different days after transplanting during March to June 2007.

\begin{tabular}{l|l|l|l|l|l|l}
\hline \multirow{2}{*}{$\begin{array}{l}\text { Treatment } \\
\text { Cucurbits) }\end{array}$} & \multicolumn{6}{c}{ Number of pumpkin beetle per plant } \\
\cline { 2 - 7 } & 7 DAT & 14 DAT & 21 DAT & 28 DAT & $\begin{array}{l}\text { Mean of } \\
\text { all DATs }\end{array}$ & Grade \\
\hline Sweet gourd & $2.75 \mathrm{a}$ & $3.25 \mathrm{a}$ & $3.50 \mathrm{a}$ & $3.00 \mathrm{ab}$ & 3.13 & $\mathrm{~S}$ \\
Bottle gourd & $1.50 \mathrm{~b}$ & $1.50 \mathrm{~b}$ & $2.25 \mathrm{~b}$ & $2.00 \mathrm{~b}$ & 1.81 & $\mathrm{MS}$ \\
Ash gourd & $1.75 \mathrm{~b}$ & $1.25 \mathrm{~b}$ & $2.00 \mathrm{~b}$ & $1.50 \mathrm{bc}$ & 1.63 & $\mathrm{MS}$ \\
Bitter gourd & $0.00 \mathrm{c}$ & $0.00 \mathrm{c}$ & $0.50 \mathrm{c}$ & $0.50 \mathrm{c}$ & 0.25 & $\mathrm{R}$ \\
Sponge gourd & $0.25 \mathrm{c}$ & $0.00 \mathrm{c}$ & $0.00 \mathrm{c}$ & $0.75 \mathrm{c}$ & 0.25 & $\mathrm{R}$ \\
Ribbed gourd & $0.50 \mathrm{c}$ & $0.00 \mathrm{c}$ & $0.00 \mathrm{c}$ & $0.25 \mathrm{c}$ & 0.19 & $\mathrm{R}$ \\
Snake gourd & $0.00 \mathrm{c}$ & $0.00 \mathrm{c}$ & $0.75 \mathrm{c}$ & $0.25 \mathrm{c}$ & 0.25 & $\mathrm{R}$ \\
Cucumber & $2.50 \mathrm{a}$ & $3.00 \mathrm{a}$ & $3.25 \mathrm{a}$ & $2.75 \mathrm{~b}$ & 2.88 & $\mathrm{~S}$ \\
Khira & $2.00 \mathrm{a}$ & $2.75 \mathrm{a}$ & $1.75 \mathrm{~b}$ & $2.00 \mathrm{~b}$ & 2.12 & $\mathrm{~S}$ \\
Muskmelon & $3.00 \mathrm{a}$ & $3.50 \mathrm{a}$ & $3.75 \mathrm{a}$ & $4.25 \mathrm{a}$ & 3.63 & $\mathrm{~S}$ \\
\hline
\end{tabular}

$\mathrm{S}=$ Susceptible $\quad \mathrm{MS}=$ Moderately susceptible $\mathrm{R}=$ Resistant

Means of the same column having common letter ( $s)$ do not differ significantly $(\mathrm{p}=0.05)$ by DMRT. Analysis was performed after square root transformation $\{\sqrt{ }(\mathrm{x}+0.5)\}$ of the original values.

Values are means of 4 replications. 
Population of red and blue pumpkin beetle on cucurbit hosts: The highest number of red pumpkin beetle per plant was recorded on musk melon, which was followed by cucumber, sweet gourd, bottle gourd and khira. Its lowest population was found on ribbed gourd, which was followed by snake gourd and sponge gourd. On the other hand, population of blue pumpkin beetle was highest on bitter gourd, which was followed by ribbed gourd and sponge gourd. Its average population was less than one on sweet gourd, cucumber, ash gourd and khira. Muskmelon, bottle gourd and snake gourd was free from blue pumpkin beetle (Fig. 1).

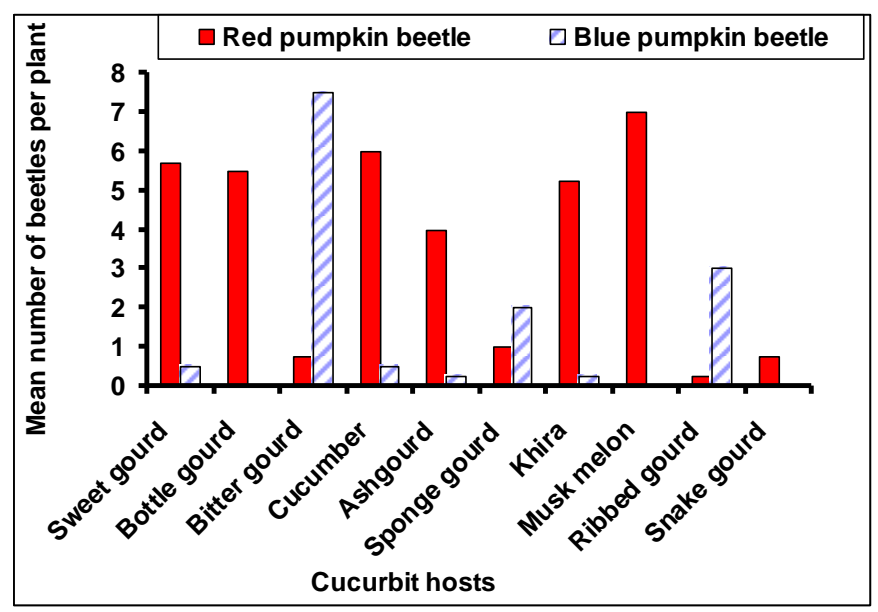

Fig. 1. Relative abundance of red and blue pumpkin beetle per plant on different cucurbit hosts grown at BSMRAU experimental farm during March to June 2007.

Results presented in Fig. 1 clearly indicate that the most preferred host of blue pumpkin beetle is the bitter gourd followed by ribbed gourd and sponge gourd. On those cucurbits population of blue pumpkin beetle was much higher than that of the red pumpkin beetle. The hosts most preferable to RPB are less preferable or not preferable to the blue pumpkin beetle. It indicates that the host choice between two species is not comparable. Similar results have also been reported by other investigators. Pradhan (1969) reported that the RPB has special preference for the leaves of cucurbit plants except those of the bitter gourd on which they do not like to feed. Nayar et al. (1995) reported that the beetles were very common on cucurbitaceous plants. They also mentioned that Rhapidopalpa foveicollis prefers pumpkin (Cucurbita maxima), while Aulacophora atripennis prefers sponge gourd (Luffa cylindrica), and both the species do not feed on bitter gourd (Momordica charantia). In general, both the species feed on Cucurbita maxima, C. pepo, Cucumis melo var. utilissimus, C. melo, C. sativus, Citrullus lanatus, C. vulgaris var. fistulosus, Luffa cylindrica, L. acutangula and Trichosanthes anguina. The beetle, R. foveicollis also feeds on Benincasa hispida and Lagenaria vulgaris (David and Ananthakrishnan 2004). 
Per cent leaf infestation by red pumpkin beetle $(\mathrm{RPB})$ : The per cent leaf infestation by RPB per plant recorded at 7, 14, 21 and 28 DAT are presented in Table 2. At 7 DAT, the highest leaf infestation per plant was recorded on muskmelon (20.70\%), which was significantly different from those of all other tested cucurbits. The second highest percentage of leaf infestation was recorded on sweet gourd $(5.25 \%)$, which was statistically similar to those found on cucumber (4.99\%), khira (4.80\%) and ash gourd $(4.25 \%)$ followed by bottle gourd $(3.70 \%)$. No leaf infestation was recorded on snake gourd.

At 14 DAT, the highest (83.47\%) leaf infestation per plant was observed on musk melon which was significantly different from those of all other cucurbits. The second highest (14.30\%) infestation was recorded on sweet gourd which was statistically similar to those of cucumber $(12.40 \%)$. Zero leaf infestation $(0.00 \%)$ was recorded on snake gourd. Similar trend of leaf infestation was observed at 21 DAT, but at 28 DAT, the highest $(95.42 \%)$ leaf infestation per plant was observed on musk melon which was significantly different from those obtained from all other cucurbit hosts. The second highest (12.40\%) leaf infestation was recorded on sweet gourd which was statistically similar to those of khira $(12.08 \%)$, cucumber $(11.80 \%)$ and ash gourd $(11.40 \%)$. The lowest $(3.52 \%)$ leaf infestation was recorded on bitter gourd and this was statistically similar to those of snake gourd $(4.00 \%)$, ribbed gourd $(4.19 \%)$ and sponge gourd (4.20\%).

Results of the present experiments indicated that muskmelon was the most preferred host of the red pumpkin beetle and the highest leaf infestation of this host was caused by the pest at different DAT. The mean of all DATs indicated that the order of preference of RPB for ten tested cucurbit hosts was muskmelon $>$ sweet gourd $>$ cucumber $>$ khira $>$ ash gourd $>$ bottle gourd $>$ sponge gourd $\geq$ ribbed gourd $\geq$ snake gourd $>$ bitter gourd (Table 2).

Table 2. Percent leaf infestation per plant by red pumpkin beetle on cucurbit hosts at different days after transplanting during March to June 2007.

\begin{tabular}{l|r|r|r|r|r}
\hline \multirow{1}{*}{\multicolumn{1}{c|}{$\begin{array}{c}\text { Cucurbit } \\
\text { hosts }\end{array}$}} & \multicolumn{5}{c}{ Percent leaf infestation per plant } \\
\cline { 2 - 6 } Sweet gourd & 7 DAT & 14 DAT & 21 DAT & 28 DAT & Mean of all DATs \\
\hline Bottle gourd & $5.25 \mathrm{~b}$ & $14.30 \mathrm{~b}$ & $15.20 \mathrm{~b}$ & $12.40 \mathrm{~b}$ & 11.79 \\
Ash gourd & $3.70 \mathrm{bc}$ & $6.80 \mathrm{~d}$ & $10.95 \mathrm{c}$ & $8.80 \mathrm{c}$ & 7.56 \\
Bitter gourd & $4.25 \mathrm{~b}$ & $8.30 \mathrm{c}$ & $11.80 \mathrm{c}$ & $11.40 \mathrm{~b}$ & 8.94 \\
Sponge gourd & $0.00 \mathrm{~d}$ & $0.00 \mathrm{f}$ & $1.50 \mathrm{e}$ & $3.52 \mathrm{~d}$ & 1.26 \\
Ribbed gourd & $2.75 \mathrm{c}$ & $3.65 \mathrm{e}$ & $6.80 \mathrm{~d}$ & $4.20 \mathrm{~d}$ & 4.35 \\
Snake gourd & $2.80 \mathrm{c}$ & $3.75 \mathrm{e}$ & $5.76 \mathrm{~d}$ & $4.19 \mathrm{~d}$ & 4.13 \\
Cucumber & $0.00 \mathrm{~d}$ & $0.00 \mathrm{f}$ & $2.00 \mathrm{e}$ & $4.00 \mathrm{~d}$ & 1.50 \\
Khira & $4.99 \mathrm{~b}$ & $12.40 \mathrm{~b}$ & $14.30 \mathrm{~b}$ & $11.80 \mathrm{~b}$ & 10.87 \\
Muskmelon & $4.80 \mathrm{~b}$ & $9.00 \mathrm{c}$ & $13.00 \mathrm{~b}$ & $12.08 \mathrm{~b}$ & 9.72 \\
\hline
\end{tabular}

Means of the same column having a common letter ( $s$ ) do not differ significantly $(p=0.05)$ by DMRT. Analysis was performed after Arc Sin $\sqrt{ } x$ transformation of the original values.

Values are means of 4 replications. 
The literature review provided variable results on the host preference of pumpkin beetle to cucurbits. Glimpses of these works related to the present study are discussed below:

Mehta and Sandhu (1989) studied 10 cucurbitaceous vegetables and noted that bitter gourd was highly resistant to the RPB, while sponge gourd and bottle gourd were resistant. The cucumber, muskmelon and water melon were moderately resistant to the pest. Roy and Pande (1990) investigated the preference order of 21 cucurbit vegetables and noted that bitter gourd was highly resistant to the beetle, while the sponge gourd and bottle gourd were moderately resistant; muskmelon and cucumber were susceptible to the pest. Roy and Pande (1991) also observed that banana squash, muskmelon and bottle gourd were the preferred hosts of the adults, while cucumber, white gourd/ash gourd, chinese okra, bitter gourd, snake gourd, watermelon and sponge gourd achieved the second order of preference to the beetle, Aulacophora foveicollis.

From the present finding it may be concluded that the most preferred host of RPB was muskmelon and was graded as the most susceptible host. Bitter gourd, sponge gourd, ribbed gourd and snake gourd were least or non preferred hosts of RPB and these may be graded as resistant hosts. The most preferred host of blue pumpkin beetle was found to be the bitter gourd.

\section{References}

Abdullah, M., 1969. Biology and control of the insect pest of cucurbits of the Indo-Pakistan subcontinent. Pakistan J. Sci. Ind. Res. 12: 127-148.

Alam, M.Z. 1969. Pest of cucurbit vegetables. In: Insect-pests of vegetables and Their Control in East Pakistan. Agri. Infor. Serv., Dept. Agri., Dacca. 87-110. pp.

Azim, M.I.I., 1966. Studies on the biology of red pumpkin beetle, Aulacophora foveicollis Lucas (Chrysomelidae: Coleoptera) in East Pakistan. M.Sc. Thesis. Department of Entomology. Bangladesh Agricultural University, Mymensingh. 95pp.

Begum, L.A.A., 2002. Host preference of fruit fly and red pumpkin beetle to different cucurbit vegetables grown in summer. M.Sc. Thesis. Department of Entomology. BSMRAU, Gazipur, Bangladesh. 65pp.

Bogawat, J. K. and S. N. Pandey, 1967. Food preference in Aulacophora sp. Indian J. Ent. 29 (4): 349-352. pp.

Butani, D.K. and M.G. Jotwani. 1984. Insects in Vegetables. Periodical Expert Book Agency. Vivek-Vihar, Delhi, India. 356pp.

David, B.V. and T.N. Ananthakrishnan. 2004. General and Applied Entomology. Tata McGrawHill Publishing Company Limited, New Delhi. 1184pp.

Dilon, N. P. S. and B. R. Sharma, 1989. Relationship between field and cage assessments for resistance to red pumpkin beetle in summer squash. Euphytica 40:63-65.

Khan, M. Z. and K. P. Hajela, 1987. Studies on Aulacophora foveicollis Lucas (Coleoptera: Chrysomelidae)-Food preference and extent of damage. Indian J. Ent. 49 (4): 457-459.

Mehta, P.K. and G.S. Sandhu, 1989. Studies on host preference and rate of feeding by red pumpkin beetle (Aulacophora foveicollis) on different cucurbits. Veg. Sci. 16 (1): 66-74.

Nath, P., 1964. Resistance of cucurbits to red pumpkin beetle. Indian J. Hort. 21 (1) :77-78.

Nath, P. and M. R. Thakur, 1965. Evaluation for red pumpkin beetle resistance in gourds. Indian J. Hort. 22 (3-4): 330-339. 
Nayar, K. K., T. N. Ananthakrishnan and B. V. David. 1995. General and Applied Entomology. Eleventh ed. Tata McGraw-Hill Publ. Co. Ltd. 4/12, Asaf Ali Road, New Delhi 110002, India. 557pp.

Pradhan, S. 1969. Insect Pests of Crops. First Edition. National Book Trust, India, New Delhi. 208pp.

Rahman, K. and R.S. Annadurai, 1985. Host selection and food utilization of the red pumpkin beetle, Raphidopalpa foveicollis (Lucas) (Chrysomelidae: Coleoptera). Proc. Indian Acad. Sci. Anim. Sci. 94: 547-556.

Rashid, M.M. 1993. Kumra Paribarer Shabji. In: Shabji Bijnan (in Bengali). Bangla Academy, Dhaka, Bangladesh. pp. 254-356.

Roy, D.C. and Y.D. Pande, 1990. Host preference and feeding rate of red pumpkin beetle (Aulacophora foveicollis) in Tripura. Indian J. Agric. Sci. 62 (2): 408-410.

Roy, D.C. and Y.D. Pande, 1991. Seasonal incidence, host preference and feeding rate of red pumpkin beetle (Raphidopalpa foveicollis) in Tripura. Indian J. Agric. Sci. 61 (8): 603607.

Steel, R. G. D. and J.H. Torrie. 1960. Principles and Procedures of Statistics. McGraw Hill Book Co. Inc., New York. 481pp.

Yawalkar, K.S. 1985. Vegetable Crops of India. Agri-Horticultural Publishing House. Nagpur. India. 374pp.

York, A. 1992. Pest of cucurbit crops: Marrow, pumpkin, squash, melon and cucumber. In: Vegetable Crop Pests. Mckinlay, R.G. (ed.). McMillan Press. Houndmills, Basingstoke, Hampshaire, and London. pp. 139-161.

(Received revised manuscript on 13 June 2012) 